\title{
Why Do Households Lack Emergency Savings? The Role of Financial Capability
}

\author{
Mathieu R. Despard ${ }^{1}\left[\right.$ ] $\cdot$ Terri Friedline $^{2} \cdot$ Stacia Martin-West $^{3}$
}

Published online: 19 May 2020

○) Springer Science+Business Media, LLC, part of Springer Nature 2020

\begin{abstract}
Many U.S. households have insufficient savings to cope with income losses, expenditure shocks, and other financial emergencies, yet little research evidence explains why. Guided by Sherraden (2013) model of financial capability, we expand on prior research that examines the role of financial knowledge by incorporating additional factors and testing income interactions to explain a greater proportion of variance concerning whether or not households have money set aside for emergencies. We analyzed data from the 2009, 2012, 2015, and 2018 National Financial Capability Surveys and found that subjective financial knowledge, financial confidence, and savings account ownership, but not objective financial knowledge, were significant and consistent predictors of having an emergency fund. Savings account ownership was the strongest predictor, accounting for an increase in the probability of having an emergency fund of $25 \%$ to $29 \%$ across study years. Adding homeownership and ability to cover expenses to the models increased the proportion of variance explained by an average of $29 \%$. Strategies to promote emergency savings should be multifaceted and include help from financial educators and counselors to create greater financial slack as well as programs and policies to increase access to short-term savings opportunities and incentives.
\end{abstract}

Keywords Emergency savings · Household saving · Financial capability · Financial knowledge financial literacy · Economic constraint $\cdot$ Financial inclusion $\cdot$ Asset ownership $\cdot$ Bank account ownership $\cdot$ Savings accounts

\section{Introduction}

Several recent studies and media stories have highlighted the lack of preparedness of most U.S. households to cope with financial emergencies such as a costly car repair or loss of income from work (Fottrell 2017; Morduch and Schneider 2017). In March 2020, as this manuscript was being drafted, the Coronavirus pandemic began threatening the livelihoods of many workers who lacked paid leave and/or could not work from home, throwing the need for having an emergency fund into sharp focus.

Mathieu R. Despard

mdespard@uncg.edu

1 Department of Social Work, University of North Carolina Greensboro, P.O. Box 26170, Greensboro, NC 27402-6170, USA

2 School of Social Work, University of Michigan, $1080 \mathrm{~S}$ University Avenue, Ann Arbor, MI 48109, USA

3 College of Social Work, University of Tennessee, 193 Polk Avenue, Suite E. Room 270, Nashville, TN 37210, USA
Financial counselors and planners have long recommended setting aside enough money to cover regular household expenses such as housing and food for at least three months in the absence of income, a standard that just over half of U.S. households could meet in 2018 (FINRA Investor Education Foundation [FINRA] 2019). Most U.S. households lacked enough liquid assets to replace even one month of income (Pew Charitable Trusts 2015).

Apart from the magnitude of the pandemic, a lack of money set aside for emergencies is a problem because financial shocks are so common. Larrimore et al. (2016) found that over a third of U.S. households experienced a health emergency and/or job loss in the prior year and nearly half (46\%) could not cover an unexpected \$400 expense with cash on hand. Adopting a broader definition of shocks to include major vehicle and home repairs, Pew Charitable Trusts (2017) found that over half of U.S. households experienced a shock in the prior year. Furthermore, shocks are not isolated events: $70 \%$ of households that experienced a shock in 2014 experienced at least another one in 2015.

Difficulty coping with financial shocks puts households at risk for hardship and other negative outcomes. Households 
without money set aside for emergencies are more likely than those with these assets to experience material hardship-difficulty meeting basic needs such as housing and food (Beverly 2001) - following financial shocks like the loss of a job (McKernan et al. 2009). Conversely, having money set aside for emergencies is associated with lessened risk for hardship (Despard et al. 2018; Gjertson 2016) and less financial strain (Shobe and Boyd 2005; Rothwell and Han 2010).

Whether or not households have enough money set aside for emergencies is informed by various explanations for saving behavior and household savings. One line of inquiry identifies a link between financial knowledge and savings (Babiarz and Robb 2014; Hilgert et al. 2003; Lusardi 2008a; Woodyard et al. 2017) as well as motivational and behavioral factors (Carroll and Samwick 1998; Grinstein-Weiss et al. 2017, 2018). Other evidence points to the importance of access to financial services and incentives (Friedline et al. 2019; Mullainathan and Shafir 2009; Nam et al. 2013; Schreiner and Sherraden 2007).

Yet, research concerning factors that specifically explain whether or not households have emergency savings is limited (Chase et al. 2011), as most prior research has focused on retirement savings. Consequently, practitioners and policy makers have little information to inform strategies to help households build emergency savings to better cope with financial uncertainty.

The purpose of this study is to examine different factors that may explain whether or not households have money set aside for emergencies. We extended analyses from prior studies that used NFCS data to examine preparedness for financial emergencies (Babiarz and Robb 2014; Woodyard et al. 2017) to contribute to the literature in four ways. First, we systematically introduced additional variables using hierarchical regression to test Sherraden's (2013) conceptual model of financial capability. We examined the degree to which objective and subjective financial knowledge, financial confidence, and savings account ownership explained the probability of having an emergency fund. Second, we tested a series of interactions to determine whether income moderated the relationship between constructs in Sherraden's model and having an emergency fund. Third, we added economic constraint and homeownership as additional controls found to be associated with household financial assets. Fourth, we assessed the stability of our findings across four cross-sectional waves (2009, 2012, 2015, and 2018) of National Financial Capability Studies (NFCS).

We found that objective financial knowledge had a weaker association with having an emergency fund than identified in prior studies. Subjective financial knowledge, financial confidence, and savings account ownership were stronger and more stable predictors. We also found that income moderated these relationships and that economic constraint accounted for a sizable proportion of the variance in having an emergency fund. Collectively, these findings offer a more complete picture of the factors associated with preparedness for financial emergencies than previously captured (Babiarz and Robb 2014; Woodyard et al. 2017). We discuss the implications of these findings-principally that financial education may be a necessary but insufficient strategy to help U.S. households build resilience in the face of financial emergencies.

This study is important because the lack of emergency savings among U.S. households has recently captured the attention of policy makers. In February 2019, the Consumer Financial Protection Bureau announced its "Start Small, Save Up" initiative to encourage consumers to establish and build emergency savings accounts. Bills recently introduced in Congress include proposals to encourage tax refund saving (Refund to Rainy Day Savings Act, S.1018, H.R. 2112) and to make it easier for employers to offer short-term savings accounts with automatic contributions (Strengthening Financial Security through Short-Term Savings Accounts Act, S.3218).

\section{Savings Behavior and Outcomes}

Economic theory offers explanations for savings behavior and outcomes. The permanent income hypothesis (PIH) holds that individuals seek to smooth consumption over time and thus will consume less if they expect their average long-term income to be less than current income (Friedman 1957). The life cycle hypothesis ( $\mathrm{LCH}$ ) posits that individuals plan and adjust their consumption and saving over their life cycle to smooth consumption (Modigliani 1966). Yet Browning and Lusardi (1996) note that the PIH and LCH are theories of consumption, with saving being merely residual, not intentional. In contrast, the precautionary savings motive contends that individuals defer present consumption to insure against future income uncertainty (Leland 1978). Similarly, the buffer-stock hypothesis suggests that individuals adjust their consumption based on a target for asset accumulation sufficient to smooth consumption given expected future income (Carroll 1997; Deaton 1991).

Although the hypotheses outlined above were formed and have primarily been tested in relation to retirement saving and long-term asset accumulation, these hypotheses may also apply to emergency savings, i.e., short-term cycles of saving and dissaving to cope with financial shocks and smooth consumption (Xiao and Noring 1994). Individuals may adjust their consumption and engage in a form of nearterm precautionary saving, setting aside some portion of income or a windfall such as a tax return or work bonus that can be used to respond to unexpected income and expenditure shocks (Collins 2015). 


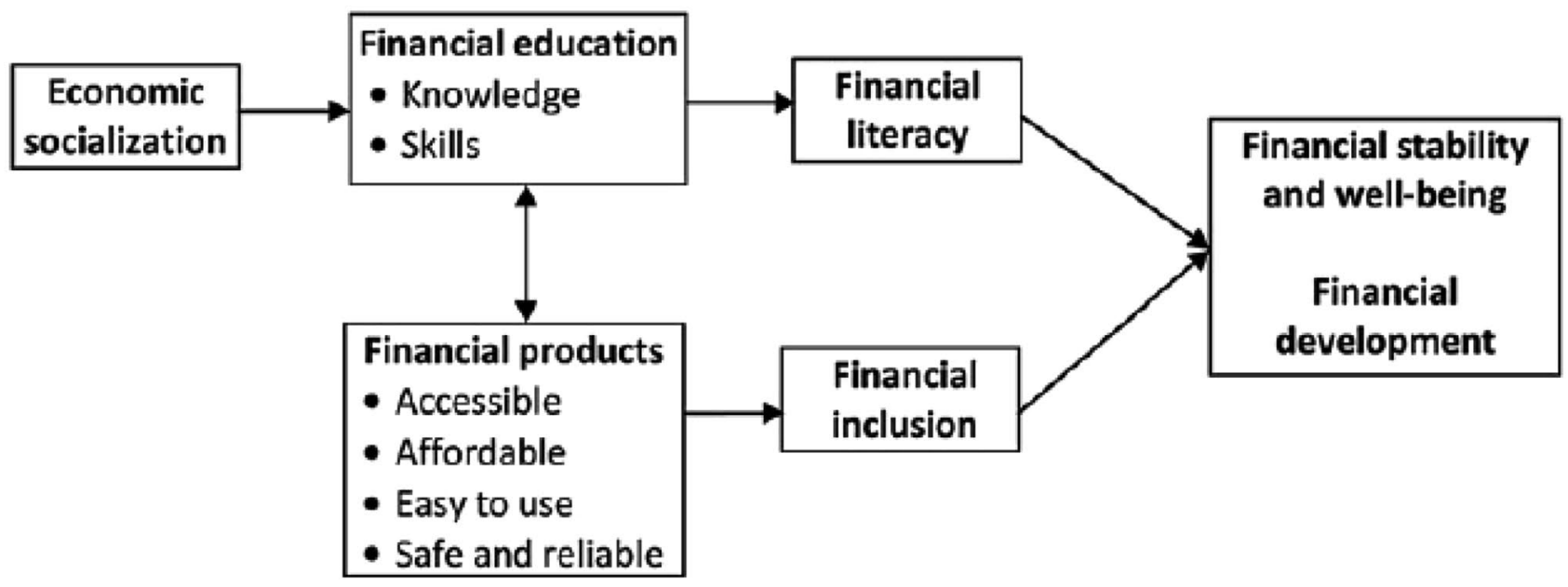

Fig. 1 Sherraden's (2015) Model of Financial Capability

Yet a precautionary savings motive alone may not be sufficient for explaining savings behavior and outcomes. Sherraden's (2013) conceptual model of financial capability posits that financial outcomes, such as having an emergency fund, occur when individuals have financial knowledge, skills, and access to financial products. For example, individuals with volatile incomes (Morduch and Schneider 2017) might recognize that an emergency fund will help them pay bills and cover unexpected expenses in months when income is less than their usual expenses. Individuals may also need to know how to build emergency funds, such as by using irregular wind falls like tax refunds (GrinsteinWeiss et al. 2016, 2018) (Fig. 1).

Individuals also need the opportunity to apply their financial knowledge and skills by accessing and using safe and affordable financial products, such as checking and savings accounts (Sherraden 2013). For example, among young adults, financial inclusion (owning a savings and/or money market account or certificate of deposit) and financial capability (financial inclusion and having received formal financial education) were associated with having emergency savings, whereas financial education alone was not (Friedline and West 2016; West and Friedline 2016). GrinsteinWeiss et al. (2015) found that average monthly savings were higher among participants in a matched savings program who received financial education compared to those who did not receive financial education, suggesting financial education and inclusion together may affect savings outcomes to a greater degree than financial inclusion alone.

In Sherraden's (2013) model, use of financial products and services is influenced by financial knowledge and skills, yet use is also conditioned by access to financial services, which vary across households based on geographic factors (Despard et al. 2017; Friedline et al. 2019). Sherraden's model thus represents a departure from economic theory that discounts the role of the environment in conditioning tastes by assuming that financial service markets are perfect.

Concerning having an emergency fund, Sherraden's (2013) model might posit that individuals need to understand the importance of saving for emergencies (financial knowledge), have budgeting and financial planning skills to ensure income can exceed expenses at least periodically to enable deposits (financial skills), and easy access to affordable savings accounts to enable asset accumulation. Guided by this model, we reviewed evidence concerning the roles of financial knowledge, financial skills, and access to financial services in influencing saving.

\section{Financial Knowledge and Literacy}

Individuals who lack financial knowledge may discount the importance of saving (Angrisani et al. 2016), particularly why it is important to control spending and set aside money for unexpected dips in income or expenditures (Lusardi 1998). Numerous prior studies draw a link between financial knowledge and financial behaviors and outcomes in the US (e.g., Bernheim and Garrett 2003; Borden et al. 2008; Hilgert et al. 2003; Lusardi and Mitchell 2007; Lusardi et al. 2017; Servon and Kaestner 2008). Hilgert et al. (2003) found a strong positive correlation between savings knowledge and saving behavior among respondents to the U.S.-based Survey of Consumers. Individuals exposed to financial education while in high school were more likely to save as adults compared to those who did not receive financial education (Bernheim et al. 2001). Lusardi and Mitchell (2011; 2017) found that individuals scoring higher on financial knowledge survey items were more likely to engage in retirement planning, compared to those with lower financial knowledge. 
Recent research has examined the association between financial knowledge and emergency savings. Babiarz and Robb (2014) and Woodyard et al (2017) analyzed data from the 2009 and 2012 NFCS, respectively, to examine relationships between objective and subjective financial knowledge, and having an emergency fund. Concerning this link, Babiarz and Robb (2014) stated, "In theory, households should accumulate a reserve of wealth to protect themselves against unexpected or uninsurable risks (Deaton 1991). This behavior, however, was more likely to characterize households who accurately recognized the probability and severity of potential financial emergencies" (p. 41). Using the 2009 NFCS data, the authors found that an additional correct financial knowledge answer was associated with $2.4 \%$ greater probability of having an emergency fund, while an additional point of subjective financial knowledge (on a seven-point likert scale) was associated with an $8 \%$ greater probability.

Woodyard et al.'s (2017) replicated study using 2012 NFCS data reported approximately $16 \%$ greater probability of having an emergency fund for each additional point of objective financial knowledge, as well as for one additional point of subjective financial knowledge. However, other studies analyzing NFCS data with a wider range of controls failed to find a link between financial knowledge and emergency savings (Friedline and West 2016; West and Friedline 2016).

Huston (2010) drew an important distinction between financial knowledge and financial literacy. Whereas the former refers to knowledge of basic financial concepts (Chase et al. 2011; Lusardi 2008b), the latter refers to having the ability and confidence to apply this knowledge. This combination of knowledge and skill is reflected in Sherraden's (2013) model of financial capability. For example, Rothwell et al. (2016) found that the relationship between financial knowledge and emergency savings was mediated by financial self-efficacy and that knowledge alone did not predict savings outcomes. Consistent with Huston's (2010) definitions, Sherraden (2013) described financial literacy as having the ability to act based on having both financial knowledge and skills. When combined with financial inclusion-the opportunity to act by accessing safe and affordable financial services-financial literacy leads to improved financial behavior.

\section{Access to and Use of Financial Services}

Whether or not a household has a savings account may affect the likelihood of having an emergency fund. Savings deposits tend to remain in accounts (Sikkel and van Meer 2015), as funds set aside in savings accounts are less tempting than funds held in other ways (e.g., checking accounts, hidden cash) that are considered "saved" via mental accounting (Thaler 1999). The accounts themselves may act as commitment devices that make it easier for individuals to followthrough on intentions to save and guard assets from nonemergency consumption (Ashraf et al. 2006; Benhabib and Bisin 2005).

Account ownership is strongly associated with savings, as is intuitively expected. Sixty-two percent of households with bank accounts set aside money for emergencies, compared to only $17 \%$ of households without bank accounts (Federal Deposit Insurance Corporation [FDIC] 2018). Participants who had a checking or savings account prior to starting a matched savings program had greater savings outcomes compared to participants without prior bank account use (Grinstein et al. 2010). Fitzpatrick (2015) found an increase in asset accumulation among families with children who transitioned into bank account ownership following an electronic public benefit transfer mandate. Income from public benefits remained stable, suggesting that the increase in assets could be attributed to account ownership.

Studies of various savings programs have demonstrated that savings increase with use of accounts and other financial products (Adams and West 2015; Collins 2015; Manturuk et al. 2015; Nam et al. 2013; Schreiner and Sherraden 2007; Sherraden et al. 2003). Individuals who owned savings accounts as teenagers were more likely to own savings accounts, certificates of deposit, and stocks as young adults compared to those who did not own savings accounts as teenagers (Friedline et al. 2016).

Account ownership and use is affected both by individual tastes and access to financial services. Financial service preferences are affected by financial literacy (Servon and Kaestner 2008), comfort, familiarity, and trust, and resources to afford bank accounts (Rengert and Rhine 2016; Servon 2017). For example, the top reasons why individuals chose not to have a bank account were not having enough money to maintain accounts (53\%) and a lack of trust in banks (30\%) (FDIC 2018).

Concerning access, Goodstein and Rhine (2017) found that bank account ownership was affected by proximity of bank branches, while Friedline et al. (2019) found an association between the availability of financial services in communities and households' savings account ownership. Conversely, prior studies have found the proximity of alternative financial services such as check cashing to be associated with use of these services (Bhutta et al. 2015; Friedline and Kepple 2017). Proximity to and availability of financial services varies by geography. Despard et al. (2017) found that bank and credit union density was greater in the Midwest and Northeast than in the South and West. Even if individuals had easy access to financial services, they may not have qualified for owning accounts due to past overdraft activity (Campbell et al. 2012). 
Savings accounts are an important means of accumulating and protecting liquid assets, yet households use other methods for setting aside money for emergencies including checking accounts, keeping money at home, and asking family members to hold cash (Christen and Mas 2009; FDIC 2018). Via mental accounting, a certain amount or proportion of one's checking account balance or cash held at home may be considered set aside or reserved for future use (Thaler 1999; Xiao and Olson 1993). Nearly a quarter of households used checking accounts to set aside emergency funds, while $11 \%$ set aside funds at home or safeguarded by family or friends (FDIC 2018).

Tax refunds are a good opportunity for households to build an emergency fund. Two-thirds of lower-income tax filers saved their refunds in a savings account, yet a third used a checking account to save their refund. Some tax filers used multiple methods, including saving some of their refund as cash and through prepaid debit card (GrinsteinWeiss et al. 2015). Thompson et al. (2020) studied tax refund savings behaviors among lower-income filers, finding that $40 \%$ of filers in Volunteer Income Tax Assistance (VITA) sites, $15 \%$ of filers using a free online tax filing program, and $33 \%$ of filers using a matched savings program, respectively, "saved" their refunds in checking accounts.

Savings accounts have structural features that make it more likely that deposited funds will remain and thus are an important means of building an emergency fund. Still, not all households use savings accounts for this purpose, due to preferences or a lack of trust, proximal access, affordability, and/or account denial.

\section{Study Purpose and Hypotheses}

Consistent with Sherraden's (2013) conceptual model of financial capability, the evidence reviewed above suggests that financial knowledge, skills, and confidence as well as savings account ownership may affect whether or not households have an emergency fund. Accordingly, we offered the following hypotheses:

H1: Greater levels of objective and subjective financial knowledge increase the probability of having an emergency fund.

$\mathrm{H} 2$ : Greater levels of financial confidence increase the probability of having an emergency fund.

H3: Owning a savings account increases the probability of having an emergency fund.

We also examined whether these hypothesized relationships varied based on household income, i.e. whether income moderated these relationships. For example, the link between financial confidence and having an emergency fund may be stronger among households with greater income.
Higher income households may have greater financial slack that enables them to maintain consumption while simultaneously addressing other financial goals such as reducing debt, building an emergency fund, and saving for retirement.

We expanded on prior studies using NFCS data that examined the role of financial knowledge (Babiarz and Robb 2014; Woodyard et al. 2017) by testing additional factors informed by Sherraden's (2013) financial capability framework - financial confidence and savings account ownership_that may more comprehensively explain whether or not a household has an emergency fund. By including financial confidence in our analyses, we assessed how financial literacy, the confidence and ability to use financial knowledge rather than financial knowledge alone (Huston 2010) was associated with having an emergency fund. By including savings account ownership, we assessed the role of access to financial services.

Our study captured a more complete range of factors conditioned both by individual and environmental factors than was reflected in prior studies using NFCS data (Babiarz and Robb 2014; Woodyard et al. 2017) to examine whether or not a household was prepared to weather a financial emergency. We also considered the role of income as a moderator with respect to explaining these relationships. In addition, we assessed these factors across four study years (2009, $2012,2015,2018$ ) reflecting the immediate aftermath of the Great Recession and a recovery marked by steady economic growth which allowed us to assess the stability of predictors corresponding to Sherraden's (2013) model. Our findings can help guide financial educators and counselors and policy makers in considering how factors in addition to financial knowledge ought to inform efforts to help individuals and households build emergency funds.

\section{Methods}

Data for this study came from the 2009, 2012, 2015, and 2018 National Financial Capability Study (NFCS) surveys commissioned by the FINRA Investor Education Foundation. NFCS surveys asked questions concerning a range of financial circumstances, behaviors, attitudes, and knowledge, such as having a budget, self-assessed credit record, use of various financial products and services, and retirement plan participation. Demographic questions captured characteristics such as age, gender, and race/ethnicity. The full survey questionnaire is available on the NFCS website. ${ }^{1}$

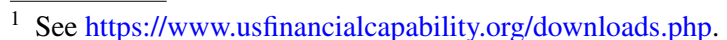




\section{Study Variables}

The dependent variable was having an emergency fund, which was coded as a dummy variable. A value of 1 was assigned if the respondent replied yes to the following question, and a value of 0 if the answer was no: "Have you set aside emergency or rainy day funds that would cover your expenses for 3 months, in case of sickness, job loss, economic downturn, or other emergencies?".

Independent variables of predictive interest used in hierarchical regression models included objective and subjective financial knowledge, financial confidence, and savings account ownership. These variables were chosen as indicators of constructs in Sherraden's (2013) conceptual model of financial capability that are hypothesized as associated with an increased probability of having an emergency fund.

Objective financial knowledge was measured using correct responses to five questions assessing knowledge concerning interest, inflation, interest rates and bond prices, mortgage interest, and investment risk (see Babiarz and Robb 2014 for a detailed description of items). Dummy variables indicating a correct answer were coded as ' 1 ' and an incorrect answer, don't know, or prefer not to say response coded as ' 0 '. Correct responses were summed to create an index variable. This coding scheme and index creation is consistent with prior research using the same items (Babiarz and Robb 2014; Knoll and Houts 2012; Woodyard et al. 2017).

In addition, these objective financial knowledge items have been used in several prior studies (e.g., Lusardi 2008b; Lusardi and Mitchell 2011) and validated by Knoll and Houts (2012) as part of a 20-item financial knowledge scale. Values ranged from zero to five and scale reliability for correct responses across these five objective financial knowledge variables was $\alpha=0.63$. Subjective financial knowledge was measured using responses to the following question: "On a scale from 1 to 7 , where 1 means very low and 7 means very high, how would you assess your overall financial knowledge?".

Financial confidence was included as a proxy for financial skills in Sherraden's (2013) model of financial capability and a reflection of Huston's (2010) definition of financial literacy. Respondents were asked, 'How strongly do you agree or disagree with the following statements? - I am good at dealing with day-to-day financial matters, such as checking accounts, credit and debit cards, and tracking expenses'. Responses were recorded using a sevenpoint likert scale where 1 indicated 'strongly disagree', 4 indicated 'neither agree nor disagree', and 7 indicated 'strongly agree'. With respect to financial skills in Sherraden's (2013) model, responses to this question operate as self-appraisals of these skills.
A dummy variable was created for savings account ownership with a value of ' 1 ' assigned if the respondent answered yes, if the household had a 'savings account, money market account, or CDs', and ' 0 ' if the answer was no. This variable was included as a predictor because having a bank account is not a necessary precondition of setting aside money for emergencies (FDIC 2018; GrinsteinWeiss et al. 2015; Thompson et al. 2020;). Furthermore, the dependent variable was measured by responses to a question about setting aside funds for emergencies, not conditional on doing so using a savings account. If owning a savings account and having an emergency fund were measuring the same phenomenon, we would expect the correlation between these two variables to be very high. However, savings account ownership was only moderately correlated with having an emergency fund ( $\mathrm{r}=0.30$ to 36 across study years) while objective and subjective financial knowledge and financial confidence were similarly correlated with having an emergency fund ( $\mathrm{r}=0.21$ to 0.33 across study years). In addition, the proportion of households that had an emergency fund but not a savings account ranged from 11 to $20 \%$ across study years which is similar to other survey estimates (FDIC 2018). These findings suggested that responses in the NFCS regarding savings account ownership and having an emergency fund were sufficiently independent and measured different phenomena.

The following set of variables were used as covariates in multivariate models: age, gender, race/ethnicity, income, education, number of children, marital, employment, health insurance status, income shock, risk tolerance, and state of residence (see Babiarz and Robb 2014; Woodyard et al. 2017). Except where otherwise noted, responses of 'don't know' or 'prefer not to say' were coded as missing values.

Prior research indicates that ability to cover expenses (Halpern-Meekin et al. 2018; Morduch and Schneider 2017; Pew Charitable Trusts 2016) is associated with savings. Ability to cover expenses also partially reflects cost of living and thus is an important variable to include in addition to income in models predicting having an emergency fund. For example, households living in urban areas with high housing costs may have greater difficulty setting aside money for emergencies, all other things being equal (e.g., income). Furthermore, homeownership is correlated with savings (Di et al. 2007; Friedline et al. 2014; Krumm and Kelly 1989; Friedline and Freeman 2016), including having an emergency fund (West and Mottola 2016). Thus, ability to cover expenses and homeownership were added as covariates to models for sensitivity tests. A dummy variable was created for homeownership to indicate whether the respondent owned their home. Lastly, ability to cover expenses was measured based on responses to the following question: 'In a typical month, how difficult is it for you to cover your expenses and pay all your bills?'. A dummy variable was 
coded as ' 1 ' if the respondent said, 'not at all difficult' and ' 0 ' if the respondent replied 'somewhat' or 'very' difficult.

\section{Samples}

Samples used in this study were from the $2009(n=28,146)$, $2012(n=25,509), 2015(n=27,564)$, and $2018(n=27,091)$ NFCS state-by-state surveys. NFCS samples were drawn using non-probability quota sampling from online survey panels. In each survey year, at least 400 responses were drawn from each state as well as the District of Columbia and national sampling weights were calculated. Four states in 2015 and two large states in 2018 were oversampled. Additional information concerning sampling methods and results is available from the NFCS website. ${ }^{2}$ Proportions of missing data for model variables ranged from $0 \%$ to $3.72 \%$ in 2009 , $0 \%$ to $3.97 \%$ in $2012,0 \%$ to $4.1 \%$ in 2015 , and $0 \%$ to $4.55 \%$ in 2018 .

\section{Analysis}

Building on Babiarz and Robb's (2014) probit regression models with objective and subjective financial knowledge as predictors of having an emergency fund, a hierarchical regression modeling approach was used to determine whether each additional variable of interest - financial confidence and savings account ownership - explained a greater amount of variance in having an emergency fund. A final model added homeownership and ability to cover expenses as additional controls. Each of these variables was retained only if the result of a Wald test was statistically significant, indicating that the variable accounted for better model fit than the preceding model without this variable.

Interaction terms were tested for income and each of the four predictors using a three-level ordered categorical indicator for income: under $\$ 50,000, \$ 50,000$ to $\$ 99,999$, and $\$ 100,000$ and above to roughly correspond to low- and moderate-income (LMI), middle income, and upper income, respectively. These interactions were tested to assess the degree to which the relationship between predictor variables (e.g., objective financial knowledge) and having an emergency fund vary by income. In addition to including significant income interaction terms in models for sensitivity tests, we also run separate probit regression models for each of the three income categories to conduct sub-sample analyses.

Sampling weights available from the NFCS datasets were added to all models to make findings nationally

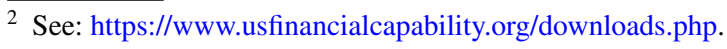

representative based on age, gender, ethnicity, and education, using data from the American Community Survey. Marginal effects were calculated for each model, holding other variables constant at their respective means. In addition, model-predicted outcomes were calculated using the margins command in Stata version 15 to indicate the proportion of respondents estimated to have an emergency fund based on each predictor variable. To convert financial literacy variables to binary indicators for the purpose of calculating predicted probabilities, values of ' 1 ' and ' 0 ' were assigned to above and at-or-below median scores, respectively. For example, the median score for subjective financial knowledge, which was measured on a seven-point scale, was five. Thus values of ' 1 ' were assigned for scores of six and seven and values of ' 0 ' for scores of five and below. Tjur's R-squared was used to identify the proportion of variance explained by probit models (Tjur 2009).

\section{Results}

\section{Sample Description}

The 2009, 2012, 2015, and 2018 samples are described in Table 1. The proportion of respondents who said they had money set aside for emergencies rose each survey year: $39 \%, 44 \%, 51 \%$, and $52 \%$ in 2009, 2012, 2015, and 2018, respectively. A nearly identical set of results was found for respondents who said they could cover their usual monthly expenses. The average number of correct responses to questions assessing financial knowledge held steady at around three out of five, declining slightly each year. Concerning financial confidence, respondents generally felt they were good at handling financial matters. Most respondents said they had a savings account, money market account, or certificate of deposit, and nearly two-thirds of respondents said they owned their homes.

Concerning demographic characteristics, most respondents in each year were White, female, and married. Ages were well dispersed, as the sample in each year had a mix of young, middle aged, and older adults. By income, roughly equal thirds of respondents in each year had annual income under $\$ 35,000, \$ 35,000$ to $\$ 75,000$, and $\$ 75,000$ and above. Slightly more than a third of respondents had a college degree or higher in each year, and most respondents indicated they were working.

There was a general trend of improved economic circumstances across sample years, as households perhaps regained economic footing coming out of the Great Recession. The proportion of respondents who said they experienced income shocks decreased, while financial confidence and tolerance for taking financial risks increased, though declined in 2018. The proportion of respondents who said they had 
Table 1 Sample descriptions

\begin{tabular}{|c|c|c|c|c|}
\hline & $\begin{array}{l}2009 \\
(n=25,556)\end{array}$ & $\begin{array}{l}2012 \\
(n=23,146)\end{array}$ & $\begin{array}{l}2015 \\
(n=25,101)\end{array}$ & $\begin{array}{l}2018 \\
(n=27,091)\end{array}$ \\
\hline Has an emergency fund & 0.39 & 0.44 & 0.51 & 0.52 \\
\hline Financial knowledge (total correct) & 3.22 & 3.09 & 3.05 & 2.80 \\
\hline Financial confidence (scale of $1-7$ ) & 5.67 & 5.76 & 5.91 & 5.13 \\
\hline Able to cover regular expenses & 0.39 & 0.43 & 0.51 & 0.54 \\
\hline Owns a savings account & 0.79 & 0.77 & 0.80 & 0.76 \\
\hline Owns a home & 0.64 & 0.63 & 0.64 & 0.62 \\
\hline \multicolumn{5}{|l|}{ Age } \\
\hline $18-25$ & 0.11 & 0.09 & 0.10 & 0.10 \\
\hline $25-34$ & 0.18 & 0.17 & 0.18 & 0.17 \\
\hline $35-44$ & 0.19 & 0.17 & 0.17 & 0.17 \\
\hline $45-54$ & 0.21 & 0.21 & 0.18 & 0.17 \\
\hline $55-64$ & 0.16 & 0.19 & 0.18 & 0.18 \\
\hline 65 or older & 0.15 & 0.17 & 0.19 & 0.20 \\
\hline Female & 0.53 & 0.55 & 0.55 & 0.56 \\
\hline \multicolumn{5}{|l|}{ Race/ethnicity } \\
\hline White & 0.76 & 0.74 & 0.73 & 0.74 \\
\hline Minority & 0.24 & 0.26 & 0.27 & 0.26 \\
\hline \multicolumn{5}{|l|}{ Income } \\
\hline Under $\$ 15,000$ & 0.12 & 0.12 & 0.11 & 0.11 \\
\hline$\$ 15-\$ 25 \mathrm{k}$ & 0.12 & 0.11 & 0.10 & 0.10 \\
\hline$\$ 25-\$ 35 \mathrm{k}$ & 0.12 & 0.11 & 0.11 & 0.11 \\
\hline$\$ 35-\$ 50 \mathrm{k}$ & 0.16 & 0.15 & 0.15 & 0.14 \\
\hline$\$ 50-\$ 75,000$ & 0.20 & 0.19 & 0.21 & 0.19 \\
\hline$\$ 75-\$ 100 \mathrm{k}$ & 0.12 & 0.12 & 0.14 & 0.14 \\
\hline$\$ 100-\$ 150 \mathrm{k}$ & 0.10 & 0.12 & 0.13 & 0.13 \\
\hline$\$ 150 \mathrm{k}$ and higher & 0.06 & 0.07 & 0.06 & 0.07 \\
\hline \multicolumn{5}{|l|}{ Education } \\
\hline High school or less & 0.25 & 0.32 & 0.23 & 0.28 \\
\hline Some college & 0.35 & 0.33 & 0.39 & 0.37 \\
\hline College degree & 0.25 & 0.22 & 0.24 & 0.22 \\
\hline Post-graduate & 0.15 & 0.13 & 0.14 & 0.13 \\
\hline Married & 0.57 & 0.57 & 0.55 & 0.53 \\
\hline Number of children in household & 0.77 & 0.73 & 0.68 & 0.66 \\
\hline \multicolumn{5}{|l|}{ Employment Status } \\
\hline Full-time & 0.40 & 0.37 & 0.40 & 0.40 \\
\hline Part-time & 0.09 & 0.09 & 0.10 & 0.09 \\
\hline Self-employed & 0.09 & 0.08 & 0.07 & 0.07 \\
\hline Homemaker & 0.09 & 0.10 & 0.09 & 0.08 \\
\hline Student & 0.05 & 0.04 & 0.05 & 0.03 \\
\hline Disabled & 0.04 & 0.05 & 0.04 & 0.05 \\
\hline Unemployed & 0.09 & 0.08 & 0.05 & 0.05 \\
\hline Retired & 0.16 & 0.19 & 0.21 & 0.23 \\
\hline Has health insurance & 0.82 & 0.82 & 0.90 & 0.90 \\
\hline Experienced income shock & 0.40 & 0.29 & 0.22 & 0.20 \\
\hline Risk tolerance (scale of 1-10) & 4.42 & 4.74 & 5.16 & 4.91 \\
\hline
\end{tabular}

Category totals may not total $100 \%$ due to rounding 
health insurance rose eight percentage points from 2012 to 2015 and 2018, perhaps due to creation of health insurance exchanges and premium subsidies under the Affordable Care Act during this interval.

\section{Hierarchical Probit Regression Results}

Results from hierarchical probit regressions for each study year are displayed in Table 2 . Wald tests were statistically significant $(p<0.001)$ for all predictor variables in all sample years. That is, each addition of a predictor variable to a probit model explained a statistically significant greater proportion of variance.

In the full model with all four predictor variables, marginal effects were statistically significant for all predictors except objective financial knowledge, which had a statistically significant association with having an emergency fund in the 2015 and 2018, but not 2009 and 2012 study years. During and soon after an economic downturn, financial knowledge may have a negligible relationship with setting aside money for emergencies.

The largest marginal effects were found for savings account ownership, which was associated with $25 \%$ to $29 \%$ greater probability of having an emergency fund $(p<0.001)$, all other things being equal. Adding savings account ownership increased the proportion of variance explained in having an emergency fund by two to three percentage points. The second and third largest marginal effects were found for subjective financial knowledge and financial confidence. One unit increases in these financial literacy indicators were associated with $5 \%$ to $6 \%$ and $2 \%$ to $5 \%$ greater probabilities of having an emergency fund $(p<0.001)$, respectively, all other things being equal.

\section{Model-Predicted Outcomes}

Table 3 displays model predictions for the proportion of respondents with an emergency fund from probit regression models with the four predictor variables. Like marginal effect results in Table 2, across all study years, model-predicted outcomes were greatest for savings account ownership. For example, in $2018,58 \%$ of respondents with a savings account had an emergency fund, compared to $35 \%$ of those without a savings account, all other things such as age and income being equal. Differences in model-predicted prevalence of having an emergency fund based on high versus low subjective financial knowledge and confidence was 7 to 11 percentage points across study years.

\section{Income Interaction Terms Results}

In all four study years, household income was moderately correlated to having an emergency fund ( $r=0.31$ to 0.37 ).
Table 2 Marginal Effects from Probit Models: Having an Emergency Fund

\begin{tabular}{|c|c|c|c|c|}
\hline & I & II & III & IV \\
\hline \multicolumn{5}{|l|}{2009 Study } \\
\hline $\begin{array}{l}\text { Objective financial } \\
\text { know }\end{array}$ & $0.017 * * *$ & $0.009 * *$ & 0.006 & 0.004 \\
\hline $\begin{array}{l}\text { Subjective financial } \\
\text { know }\end{array}$ & & $0.077 * * *$ & $0.065 * * *$ & $0.063 * * *$ \\
\hline Financial confidence & & & $0.027 * * *$ & $0.024 * * *$ \\
\hline $\begin{array}{l}\text { Savings account } \\
\text { ownership }\end{array}$ & & & & $0.284 * * *$ \\
\hline Wald Chi Square & & $416.38 * * *$ & $90.24 * * *$ & $517.76^{* * *}$ \\
\hline Tjurs R2 & 0.208 & 0.232 & 0.237 & 0.262 \\
\hline $\mathrm{N}$ & 25,765 & 25,479 & 25,313 & 25,094 \\
\hline \multicolumn{5}{|l|}{2012 Study } \\
\hline $\begin{array}{l}\text { Objective financial } \\
\text { know }\end{array}$ & $0.015 * * *$ & $0.008^{*}$ & 0.006 & 0.001 \\
\hline $\begin{array}{l}\text { Subjective financial } \\
\text { know }\end{array}$ & & $0.066 * * *$ & $0.050 * * *$ & $0.048 * * *$ \\
\hline Financial confidence & & & $0.034 * * *$ & $0.031 * * *$ \\
\hline $\begin{array}{l}\text { Savings account } \\
\text { ownership }\end{array}$ & & & & $0.248 * * *$ \\
\hline Wald Chi Square & & $247.97 * * *$ & $99.07 * * *$ & $372.61 * * *$ \\
\hline Tjurs R2 & 0.246 & 0.261 & 0.266 & 0.286 \\
\hline $\mathrm{N}$ & 23,282 & 22,980 & 22,885 & 22,696 \\
\hline \multicolumn{5}{|l|}{2015 Study } \\
\hline $\begin{array}{l}\text { Objective financial } \\
\text { know }\end{array}$ & $0.027 * * *$ & $0.022 * *$ & $0.017 * * *$ & $0.013 * * *$ \\
\hline $\begin{array}{l}\text { Subjective financial } \\
\text { know }\end{array}$ & & $0.077 * * *$ & $.054 * * *$ & $0.056 * * *$ \\
\hline Financial confidence & & & $.051 * * *$ & $0.046 * * *$ \\
\hline $\begin{array}{l}\text { Savings account } \\
\text { ownership }\end{array}$ & & & & $0.287 * * *$ \\
\hline Wald Chi Square & & $361.18^{* * *}$ & $185.34 * * *$ & $574.28 * * *$ \\
\hline Tjurs R2 & 0.209 & 0.228 & 0.238 & 0.265 \\
\hline $\mathrm{N}$ & 25,195 & 24,906 & 24,841 & 24,646 \\
\hline \multicolumn{5}{|l|}{2018 Study } \\
\hline $\begin{array}{l}\text { Objective financial } \\
\text { know }\end{array}$ & $0.024 * * *$ & $0.018 * * *$ & $0.012 * * *$ & $0.009 * *$ \\
\hline $\begin{array}{l}\text { Subjective financial } \\
\text { know }\end{array}$ & & $0.081 * * *$ & $0.061 * * *$ & $0.058 * * *$ \\
\hline Financial confidence & & & $0.046 * * *$ & $0.043 * * *$ \\
\hline $\begin{array}{l}\text { Savings account } \\
\text { ownership }\end{array}$ & & & & $0.275 * * *$ \\
\hline Wald Chi Square & & $444.54 * * *$ & $176.04 * * *$ & $537.96 * * *$ \\
\hline Tjurs R2 & 0.237 & 0.261 & 0.270 & 0.298 \\
\hline $\mathrm{N}$ & 24,664 & 24,337 & 24,264 & 23,972 \\
\hline
\end{tabular}

Models included a nationally representative sampling weight. Marginal effects are calculated at sample means

$* p<.05 ; * * p<.01 ; * * * p<.001$

The prevalence of having an emergency fund rose with income. For example, in 2018, the prevalence rate among low- and moderate-income $(<\$ 50,000)$, middle-income 
Table 3 Model predicted Emergency fund outcomes_-final models

\begin{tabular}{|c|c|c|c|c|c|c|c|c|c|c|c|c|}
\hline & \multicolumn{3}{|l|}{2009} & \multicolumn{3}{|l|}{2012} & \multicolumn{3}{|l|}{2015} & \multicolumn{3}{|l|}{2018} \\
\hline & Yes & No & $\mathrm{p}$ & Yes & No & $\mathrm{p}$ & Yes & No & $\mathrm{p}$ & Yes & No & $\mathrm{P}$ \\
\hline & 38.05 & & & 42.93 & & & 49.45 & & & 52.63 & & \\
\hline High objective. fin. know. $^{\text {a }}$ & 38.93 & 37.23 & * & 43.77 & 42.27 & $*$ & 51.76 & 47.96 & $* * *$ & 54.54 & 51.56 & $* * *$ \\
\hline High subjective. fin. know. ${ }^{a}$ & 44.30 & 34.42 & $* * *$ & 46.95 & 39.91 & $* * *$ & 53.97 & 45.94 & $* * *$ & 58.19 & 48.74 & $* * *$ \\
\hline High financial confidence ${ }^{a}$ & 43.33 & 33.76 & $* * *$ & 48.88 & 38.16 & $* * *$ & 55.71 & 44.49 & $* * *$ & 58.76 & 47.58 & $* * *$ \\
\hline Owns savings account & 42.40 & 19.79 & $* * *$ & 47.09 & 27.19 & $* * *$ & 54.19 & 30.46 & $* * *$ & 57.82 & 34.95 & $* * *$ \\
\hline
\end{tabular}

${ }^{\mathrm{a}}$ Above-median scores

(\$50,000 to $\$ 99,999)$ and high-income $(\$ 100,000$ and higher) was $35 \%, 61 \%$, and $76 \%$, respectively.

Income moderated the relationship between most predictor variables and having an emergency fund. For the 2009 sample, interactions between income and subjective financial knowledge $(p<0.001)$, financial confidence $(p<0.01)$, and savings account ownership $(p<0.05)$ were statistically significant for having an emergency fund. For all other study years, significant income interaction terms were found for objective and subjective financial knowledge, and financial confidence.

To help better understand the moderating influence of income on the relationship between predictor variables and having an emergency fund, sub-sample analyses were conducted for each income group. Results of sub-sample analyses are displayed in Table 4. Marginal effects were statistically significant for all income groups and all predictor variables, except for objective financial knowledge, which had a significant association with having an emergency fund only among low- and moderate-income households in 2015 and 2018. That is, three out of four indicators of financial capability were consistent and statistically significant predictors of having an emergency fund across all income groups and in all study years.

However, the magnitude of marginal effects differed by income. Without exception, marginal effects were highest among middle-income $(\$ 50,000$ to $\$ 99,999)$ households across all study years.

\section{Sensitivity Tests}

To assess the stability of findings, a model adding statistically significant interaction terms (Model V) and a model adding ability to cover expense and homeownership as additional controls (Model VI) were run. As seen Table 5, the main results reported in Table 2 were largely unchanged, with two exceptions. First, objective financial knowledge was no longer a significant predictor of having an emergency fund in 2018. Second, the magnitude of the four predictors all declined after adding ability to cover expenses and homeownership, while the proportion of variance explained (Tjur's $\mathrm{R}^{2}$ ) rose substantially — by an average of $29 \%$ across study years.

\section{Discussion}

In this study, we examine constructs from Sherraden's (2013) conceptual model of financial capability to explain variation in having money set aside for emergencies, an important indicator of household financial well-being. We

Table 4 Income Sub-Sample Analysis: Marginal Effects from Probit Models

\begin{tabular}{|c|c|c|c|c|c|}
\hline & OFK & SFK & $\mathrm{FC}$ & SAV & $\mathrm{N}$ \\
\hline \multicolumn{6}{|l|}{2009 Study } \\
\hline Under $\$ 50,000$ & 0.006 & $0.040 * * *$ & $0.019 * * *$ & $0.228 * * *$ & 12,847 \\
\hline$\$ 50-\$ 99,000$ & 0.001 & $0.093 * * *$ & $0.028 * * *$ & $0.348 * * *$ & 7,997 \\
\hline $\begin{array}{l}\$ 100 \mathrm{k} \text { and } \\
\text { higher }\end{array}$ & 0.014 & $0.075 * * *$ & $0.024 * * *$ & $0.270 * * *$ & 4,250 \\
\hline \multicolumn{6}{|l|}{2012 Study } \\
\hline Under $\$ 50,000$ & 0.001 & $.028 * * *$ & $0.021 * * *$ & $0.211 * * *$ & 11,113 \\
\hline$\$ 50-\$ 99,000$ & 0.003 & $0.069 * * *$ & $0.040 * * *$ & $0.250 * * *$ & 7,275 \\
\hline $\begin{array}{l}\$ 100 \mathrm{k} \text { and } \\
\text { higher }\end{array}$ & 0.002 & $0.056 * * *$ & $0.029 * *$ & $0.203 * * *$ & 4,308 \\
\hline \multicolumn{6}{|l|}{2015 Study } \\
\hline Under $\$ 50,000$ & $0.014 * *$ & $0.041 * * *$ & $0.035^{* * *}$ & $0.259 * * *$ & 11,307 \\
\hline$\$ 50-\$ 99,000$ & 0.007 & $0.075 * * *$ & $0.058 * * *$ & $0.300 * * *$ & 8,618 \\
\hline $\begin{array}{l}\$ 100 \mathrm{k} \text { and } \\
\text { higher }\end{array}$ & 0.012 & $0.048 * * *$ & $0.031^{*}$ & $0.203 * * *$ & 4,721 \\
\hline \multicolumn{6}{|l|}{2018 Study } \\
\hline Under $\$ 50,000$ & $0.010^{*}$ & $0.052 * * *$ & $0.036^{* * *}$ & $0.256 * * *$ & 10,700 \\
\hline$\$ 50-\$ 99,000$ & 0.005 & $0.056 * * *$ & $0.046 * * *$ & $0.263 * * *$ & 8,328 \\
\hline $\begin{array}{l}\$ 100 \mathrm{k} \text { and } \\
\text { higher }\end{array}$ & 0.011 & $0.048 * * *$ & $0.034 * * *$ & $0.221 * * *$ & 4,944 \\
\hline
\end{tabular}

$O F K$ objective financial knowledge, $S F K$ subjective financial knowledge, $F C$ financial confidence, $S A V$ savings account ownership

Marginal effects are calculated at sample means $* p<.05 ; * * p<.01$; $* * * p<.001$ 
Table 5 Robustness checks with full models

\begin{tabular}{|c|c|c|}
\hline & $\mathrm{V}$ & VI \\
\hline \multicolumn{3}{|l|}{2009 Study } \\
\hline Objective financial know & 0.006 & 0.002 \\
\hline Subjective financial know & $0.054 * * *$ & $0.043^{* * *}$ \\
\hline Financial confidence & $0.023 * * *$ & $0.014 * *$ \\
\hline Savings account ownership & $0.284 * * *$ & $0.252 * * *$ \\
\hline Tjurs $\mathrm{R}^{2}$ & 0.261 & 0.349 \\
\hline $\mathrm{N}$ & 25,094 & 24,784 \\
\hline \multicolumn{3}{|l|}{2012 Study } \\
\hline Objective financial know & -0.001 & 0.015 \\
\hline Subjective financial know & $0.039 * * *$ & $0.028 * * *$ \\
\hline Financial confidence & $0.026 * * *$ & $0.017 * * *$ \\
\hline Savings account ownership & $0.259 * * *$ & $0.221 * * *$ \\
\hline Tjurs $\mathrm{R}^{2}$ & 0.283 & 0.364 \\
\hline $\mathrm{N}$ & 22,696 & 22,446 \\
\hline \multicolumn{3}{|l|}{2015 Study } \\
\hline Objective financial know & $0.011^{*}$ & $0.009 *$ \\
\hline Subjective financial know & $0.052 * * *$ & $0.041 * * *$ \\
\hline Financial confidence & $0.038 * * *$ & $0.024 * * *$ \\
\hline Savings account ownership & $0.296 * * *$ & $0.262 * * *$ \\
\hline Tjurs $\mathrm{R}^{2}$ & 0.262 & 0.334 \\
\hline $\mathrm{N}$ & 24,646 & 24,340 \\
\hline \multicolumn{3}{|l|}{2018 Study } \\
\hline Objective financial know & 0.005 & 0.002 \\
\hline Subjective financial know & $0.058 * * *$ & $0.046 * * *$ \\
\hline Financial confidence & $0.039 * * *$ & $0.029 * * *$ \\
\hline Savings account ownership & $0.287 * * *$ & $0.244 * * *$ \\
\hline Tjurs $\mathrm{R}^{2}$ & 0.293 & 0.367 \\
\hline $\mathrm{N}$ & 23,972 & 23,653 \\
\hline
\end{tabular}

Results reflect marginal effects from Probit regression models calculated at sample means, model V added statistically significant income interaction terms model VI added ability to cover expenses and homeownership as additional controls

$* p<.05 ; * * p<.01 ; * * * p<.001$

use four cross-sectional panels of the National Financial Capability Study (NFCS) state-by-state survey from 2009 to 2018 and produce remarkably stable results. Three of the four financial capability constructs-subjective financial knowledge, financial confidence, and savings account ownership—are stable and statistically significant predictors of having an emergency fund across all four study years and for all income levels. These findings are consistent with our hypotheses and prior research. However, one difference is regarding objective financial knowledge, which has a statistically significant association with having an emergency fund only in certain study years and for certain income groups.

The role of objective financial knowledge in explaining emergency savings may be over-estimated in prior studies using NFCS data (Babiarz and Robb 2014; Woodyard et al. 2017) due to the omission of other predictors. A fuller picture of emergency savings emerges by including additional constructs - financial confidence and savings account ownership that comprise Sherraden's (2013) model of financial capability, as well as incorporating additional controls such as ability to cover expenses and homeownership. The key implication of this conclusion is that it may take more than financial education - the typical remedy for a lack of financial knowledge - to influence households' preparedness for financial emergencies. It may take other types of interventions such as financial counseling and savings programs to influence this outcome.

Of the four constructs tested, savings account ownership was the strongest predictor of having an emergency fund. Households with savings accounts or other savings vehicles may find it easier to set aside money for emergencies as these financial products may act as commitment devices (Benhabib and Bisin 2005). This idea is consistent with prior findings concerning the "stickiness" of savings deposits (Sikkel and van Meer 2015) and the association between tax-time savings account deposits and reduced risk of material hardship among low- and moderate-income (LMI) households (Grinstein-Weiss et al. 2016). Having a savings account also enables households to take advantage of split direct deposit of paychecks, tax-time savings interventions (GrinsteinWeiss et al. 2017), impulse savings programs (Manturuk et al. 2015), and other incentive programs that require a savings account or similar product to participate. Yet nearly a quarter of US households lack a savings account (FDIC 2018), and some households may close their savings account when experiencing an income shortfall (Rhine et al. 2016).

Financial confidence and subjective financial knowledge also had statistically significant associations with having an emergency fund, while objective financial knowledge had the weakest association. This finding underscores the important distinction between financial knowledge and literacy, whereas the latter refers to the ability to understand and use financial information (Huston 2010). Individuals lacking financial confidence may need support and guidance through financial counseling and coaching to take steps to build an emergency fund, not just to have information about the need to do so.

That objective financial knowledge had less of an association than other factors with having money set aside for emergencies may be related to how it was assessed in the NFCS survey. The objective financial knowledge items assess knowledge concerning compound interest, inflation, bond pricing, mortgage payments, and portfolio diversification. Despite the popularity of using these items in research on consumer finance, these items may be poor indicators of financial knowledge for individuals who have limited or no experience with credit cards, owning a home, and/or retirement accounts. This relates to what Sherraden (2013) observes as the interaction between financial knowledge and skills and financial inclusion. 
For example, there are over 45 million consumers who are "credit invisible" meaning they lack a credit history with the three credit reporting agencies or have "thin" credit histories that cannot be scored. As a result, these consumers lack access to credit (Brevoort et al. 2016), which means they may be unfamiliar with credit-related financial concepts such as loan interest. Similarly, over a third of the NFCS 2018 sample do not own homes and a majority have no investments, which means they are probably unfamiliar with mortgage and investment concepts, respectively. Thus, given that higher-income consumers are more likely to enjoy access to credit and own homes and investments, these items may have a distinct socioeconomic status bias, while not directly measuring knowledge concerning precautionary saving.

There are many other ways to measure financial knowledge (Fernandes et al. 2014), including an understanding of concepts that are more closely related to emergency savings, such as budgeting, cash flow, comparison shopping, automatic saving options, and use of financial services. Measured differently, objective financial knowledge may have a stronger association with having money for emergencies than we discovered. Our finding concerning subjective financial knowledge corroborates this point. The lower respondents assessed their financial knowledge, the less likely they reported having an emergency fund. This suggests that financial education efforts should be tailored to address specific financial health concerns such as the need to build emergency savings. This idea is consistent with the "just in time" hypothesis of financial education based on the recognition that outcomes of general financial education are limited and decay over time (Fernandes et al. 2014).

We also find evidence that income moderates the relationship between predictor variables and having an emergency fund. Factors such as subjective financial knowledge and financial confidence play a larger role in predicting whether middle-income households have an emergency fund compared to other income groups. It may be that middle-income households, in experiencing or striving to achieve upward mobility are accessing a more complex set of personal finance decisions (e.g., managing credit card debt while repaying student loans) amidst less of an income buffer compared to high-income households. Whatever the case, financial educators and counselors might anticipate different types of challenges in building emergency savings among participants with different income levels (Anderson et al. 2004).

\section{Study Limitations}

Our study has important limitations to note. First, we did not directly observe having money set aside for emergencies. Also, survey respondents might not have had an accurate idea of the amount of money equal to three months of their household's expenses. In addition, households may have had emergency savings, albeit in amounts less than three months of expenses. This circumstance was not observed through the NFCS surveys. Second, as we note above, a broader and more relevant set of indicators of financial knowledge may have had a different association with money set aside for emergencies. Third, our findings are correlational. Readers should not infer from our findings that having greater financial knowledge or confidence or owning a savings account will result in households having emergency funds. Also, unobserved factors may explain both the independent and dependent variables in our study. The same set of motivations, propensities, or tastes might explain whether individuals have savings accounts or high financial confidence and why they have enough money set aside for emergencies.

This study examines predictors of households having money set aside to help cope with financial emergencies, guided by Sherraden's (2013) conceptual model of financial capability. We find that subjective financial knowledge, financial confidence, and savings account ownership are steady predictors of having money for emergencies while objective financial knowledge is not. Efforts to increase objective financial knowledge alone may be insufficient; financial counseling and coaching interventions can help households build financial skills and confidence and access savings accounts that meet their needs to prepare for emergencies. Changes in public policies concerning access to safe and affordable financial products and services and targeted savings programs are also needed.

\section{Implications and Conclusion}

An overall implication of our findings is that interventions to improve financial knowledge alone may not help households build an emergency fund. Interventions such as financial counseling and coaching are needed to help individuals gain new skills and confidence to save. Yet, we also find that ability to cover expenses alone explains seven to nine percent of variation in having an emergency fund. A household is unlikely to set aside money for emergencies if income does not at least occasionally exceed usual expenses to create the financial slack necessary to build assets (Barr 2012; Mullainathan and Shafir 2009). Thus, financial counselors and coaches could help households identify ways to create financial slack, not just through reducing expenses-the usual focus of these services, but by maximizing use of existing public resources (e.g. tax credits, housing, food, child care, and health care subsidies) and increasing income (e.g., job training, additional education, microenterprise, small business development) (Anderson et al. 2004). Another strategy is to integrate financial education and counseling in services 
and systems aimed at increasing household income, such as workforce development.

Practitioners could also integrate financial counseling and coaching with access to and use of financial services, as is frequently done in both matched savings and "second chance" bank account programs. In a program designed to assist households that had been reported to Chex Systems for account mismanagement, targeted financial education and the opportunity to open both a checking and savings account showed positive outcomes. Most who had opened a checking or savings account still had the account one to three years later, most repaid debts owed to financial institutions, and $75 \%$ routinely kept up with their account transactions (Haynes-Bordas et al. 2008). The integration of financial education and counseling with access to financial services reflects Sherraden's (2013) financial capability model and is consistent with prior research indicating better financial outcomes associated with owning bank accounts in addition to receiving financial education compared to financial education alone (Friedline and West 2016; West and Friedline 2016).

Our findings affirm the importance of public policies to promote financial inclusion. Nearly a third of households surveyed said products offered by financial institutions do not meet their needs for saving (Pew Charitable Trusts 2016). Only $9 \%$ of over 1600 bank branches surveyed indicated that they have entry-level accounts that meet national product standards for safety and affordability (Friedline et al. 2017). However, evidence from the FDIC's pilot study of Model Safe Accounts suggests that simple, low-cost savings accounts can be offered to a wider range of customers without introducing risk to banks (FDIC 2012). The "Borrow and Save" program provides installment loans to credit union members as an alternative to expensive payday loans with a feature in which a portion of loan repayments are allocated to a savings account (National Federation of Community Development Credit Unions and Filene 2015). Thus, to help households build an emergency fund, financial institutions need to consider products and services that meet the needs of a wider range of customers.

In addition, households can benefit from various programs to encourage and incentivize saving. Of note, a matched emergency savings program administered by a community development financial institution demonstrated that very low-income participants, some without earned income, could successfully save $\$ 500$ over a 2 year period to ultimately receive a 2:1 match (Adams and West 2015). Matched tax-time savings models including \$aveNYC have demonstrated moderate effects related to increased savings amounts among lower-income households (Key et al. 2015). To bring tax time savings to scale for lower-income workers, Edin et al. (2015) proposed the Rainy Day Earned Income Tax Credit (EITC), a matched savings vehicle that allows
EITC recipients to hold back $20 \%$ of their refund for a $50 \%$ match available to them 6 months after their first refund check.

Other programs that do not offer a savings match have also been shown effective. Manturuk et al. (2015) found that encouragement and opportunity to direct small amounts toward a savings account linked to prepaid debt cards via text messages helped individuals build an emergency fund. Messages encouraging lower-income online tax filers to save their refunds have shown success concerning savings deposits (Grinstein-Weiss et al. 2017). Tax-time savings deposits have also been found to lessen risk for material hardship (Grinstein-Weiss et al. 2016), suggesting saved refunds are being used as emergency resources. In tandem with policies to create slack in household budgets, initiatives to increase access to responsive financial products and services, these targeted savings programs offer promising and scalable solutions to households' persistent lack of emergency savings.

The workplace is another promising channel for promoting emergency savings. Employers can offer split direct deposit and match employees' deposits, as is done by the Red Tab Foundation for employees of Levi Strauss and Company in partnership with the nonprofit EARN, which offers the digital platform to facilitate employee savings (Red Tab Foundation, 2019). Rhino Foods' Income Advance program automatically rolls over employees' payroll-deducted small-dollar installment loan payments to savings deposits once the loan has been repaid (FINRA and Filene Research Institute 2017). Most (71\%) employees indicated they would somewhat or very likely enroll in a "rainy day" savings program with payroll deduction if offered by their employer (Harvey et al. 2018).

Funding No funding was received to support this study.

Data Availability This article uses data from datasets made publicly available by the FINRA Investor Education Foundation that contain de-identified survey data.

\section{Compliance with Ethical Standards}

Conflict of interest Mathieu Despard, Terri Friedline and Stacia Martin-West declares that they have no conflict of interest.

Research Involving Human and Animal Rights This article does not contain any studies with human participants performed by any of the authors.

\section{References}

Adams, D., \& West, S. (2015). Asset building among low income adults: An exploratory study with participants in an emergency 
savings program. Journal of Community Practice, 23(3-4), 436-461. https://doi.org/10.1080/10705422.2015.1091421.

Anderson, S. G., Zhan, M., \& Scott, J. (2004). Targeting financial management training at low-income audiences. Journal of Consumer Affairs, 38(1), 167-177. https://doi. org/10.1111/j.1745-6606.2004.tb00470.x.

Angrisani, M., Kapteyn, A., \& Lusardi, A. (2016). The National Financial Capability Study: Empirical findings from the American Life Panel Survey. Washington, DC: The George Washington University, Global Financial Literacy Excellence Center. Retrieved from https://gflec.org/wp-content/uploads/2016/11/ NFCS_ALP_Report_Final_UPDATED.pdf

Ashraf, N., Karlan, D., \& Yin, W. (2006). Tying Odysseus to the mast: Evidence from a commitment savings product in the Philippines. The Quarterly Journal of Economics, 121(2), 635-672. https://doi.org/10.1162/qjec.2006.121.2.635.

Babiarz, P., \& Robb, C. A. (2014). Financial literacy and emergency saving. Journal of Family and Economic Issues, 35, 40-50. https://doi.org/10.1007/s10834-013-9369-9.

Barr, M. S. (2012). Introduction. No slack: The financial lives of low-income Americans (pp. 1-21). Washington, DC: Brookings Institution.

Benhabib, J., \& Bisin, A. (2005). Modeling internal commitment mechanisms and self-control: A neuroeconomics approach to consumption-saving decisions. Games and Economic Behavior, 52, 460-492. https://doi.org/10.1016/j.geb.2004.10.004.

Bernheim, B. D., \& Garrett, D. M. (2003). The effects of financial education in the workplace: evidence from a survey of households. Journal of Public Economics, 87(7), 1487-1519. https:// doi.org/10.1016/S0047-2727(01)00184-0.

Bernheim, B. D., Garrett, D. M., \& Maki, D. M. (2001). Education and saving: The long-term effects of high school financial curriculum mandates. Journal of Public Economics, 80, 435-465. https://doi.org/10.1016/S0047-2727(00)00120-1.

Beverly, S. G. (2001). Material hardship in the United States: Evidence from the Survey of Income and Program Participation. Social Work Research, 25(3), 143-151. https://doi.org/10.1093/ swr/25.3.143.

Bhutta, N., Skiba, P. M., \& Tobacman, J. (2015). Payday loan choices and consequences. Journal of Money, Credit and Banking, 47(2-3), 223-260. https://doi.org/10.1111/jmcb.12175.

Borden, L. M., Lee, S. A., Serido, J., \& Collins, D. (2008). Changing college students' financial knowledge, attitudes, and behavior through seminar participation. Journal of Family and Economic Issues, 29(1), 23-40. https://doi.org/10.1007/s1083 4-007-9087-2.

Brevoort, K. P., Grimm, P., \& Kambara, M. (2016). Credit invisibles and the unscored. Cityscape: A Journal of Policy Development and Research, 18, 9-33. https://www.jstor.org/stable/26328254

Browning, M, \& Lusardi, A. (1996). Household saving: Micro theories and micro facts. Journal of Economic Literature, 34(4), 17971855. https://www.jstor.org/stable/2729595

Campbell, D., Martínez-Jerez, F. A., \& Tufano, P. (2012). Bouncing out of the banking system: An empirical analysis of involuntary bank account closures. Journal of Banking \& Finance, 36(4), 1224-1235. https://doi.org/10.1016/j.jbankfin.2011.11.014.

Carroll, C. D. (1997). Buffer-stock saving and the life cycle/permanent income hypothesis. The Quarterly Journal of Economics, 112(1), 1-55. https://doi.org/10.1162/003355397555109.

Carroll, C. D., \& Samwick, A. A. (1998). How important is precautionary saving? Review of Economics and Statistics, 80(3), 410-419. https://doi.org/10.1162/003465398557645.

Chase, S., Gjertson, L., \& Collins, M.J. (2011). Coming up with cash in a pinch: Emergency savings and its alternatives. Madison, WI: University of Wisconsin-Madison, Center for Financial Security. Retrieved from https://static.newamerica.org/attachment
s/8422-much-ado-about-emergency-savings/Michael\%20Col lins\%20Paper.f9bb1db94b8540b49e6726195dbbb3d2.pdf

Christen, B., \& Mas, I. (2009). It's time to address the microsavings challenge, scalably. Enterprise Development and Microfinance, 20(4), 274-285. https://doi.org/10.3362/1755-1986.2009.031.

Collins, M. J. (2015). A Fragile Balance: Emergency Savings and Liquid Resources for Low-Income Consumers. New York: Palgrave Macmillan.

Deaton, A. S. (1991). Saving and liquidity constraints. Econometrica, 59(5), 1221-1248. https://doi.org/10.2307/2938366.

Despard, M., Friedline, T., \& Refior, K. (2017). Can post offices increase access to financial services? A geographic investigation of financial services availability. Ann Arbor, MI: University of Michigan, Center on Assets, Education, \& Inclusion (AEDI). https ://aedi.ssw.umich.edu/publications/1700-can-post-offices-incre ase-access-to-financial-services

Despard, M., Guo, S., Grinstein-Weiss, M., Russell, B., Oliphant, J., \& de Ruyter, A. (2018). The mediating role of assets in explaining hardship risk among households experiencing financial shocks. Social Work Research, 42, 147-158. https://doi.org/10.1093/swr/ svy012.

Di, Z., Belsky, E., \& Liu, X. (2007). Do homeowners achieve more household wealth in the long run? Journal of Housing Economics, 16(3-4), 274-290. https://doi.org/10.1016/j.jhe.2007.08.001.

Edin, K., Greene, S., Halpern-Meekin, S., \& Levin, E. (2015). The rainy day EITC: A reform to boost financial security by helping low-wage workers build emergency savings. Retrieved from https ://cfed.org/assets/pdfs/The_Rainy_Day_EITC.pdf

Federal Deposit Insurance Corporation. (2018). 2017 FDIC National Survey of Unbanked and Underbanked Households. Washington, DC: FDIC. Retrieved from https://www.fdic.gov/householdsurvey /2017/2017report.pdf

Federal Deposit Insurance Corporation. (2012). FDIC Model Safe Accounts Pilot: Final Report. Washington, DC: FDIC. Retrieved from https://www.fdic.gov/consumers/template/SafeAccountsFin alReport.pdf

Fernandes, D., Lynch, J., \& Netemeyer, R. (2014). Financial literacy, financial education, and downstream financial behaviors. Management Science, 60(8), 1861-1883. https://doi.org/10.1287/ mnsc.2013.1849.

FINRA Investor Education Foundation \& Filene Research Institute. (2017). Employer-sponsored small-dollar loan: Feasibility study report. Retrieved from https://filene.org/do-something/programs/ employer-sponsored-small-dollar-loans

FINRA Investor Education Foundation (2019). Financial capability in the United States 2018. Retrieved from https://www.usfinancia lcapability.org/downloads/NFCS_2018_Report_Natl_Findings. pdf

Fitzpatrick, K. (2015). Does "banking the unbanked" help families to save? Evidence from the United Kingdom. Journal of Consumer Affairs, 49(1), 223-249. https://doi.org/10.1111/joca.12055.

Fottrell, Q. (2017, April 5). Half of US working families are living paycheck to paycheck. The New York Post. Retrieved from https ://nypost.com/2017/04/05/half-of-us-working-families-are-livin g-paycheck-to-paycheck/

Friedline, T., Johnson, P., \& Hughes, R. (2014). Toward healthy balance sheets: Are savings accounts a gateway to young adults' asset diversification and accumulation? Federal Reserve Bank of St. Louis Review, 96(4), 359-389. https://files.stlouisfed.org/files/ htdocs/publications/review/2014/q4/friedline.pdf

Friedline, T., Despard, M., \& Chowa, G. A. N. (2016). Preventive policy strategy for banking the unbanked: Savings accounts for teenagers? Journal of Poverty, 20, 2-33. https://doi.org/10.1080/10875 549.2015.1015068.

Friedline, T., \& Freeman, A. (2016). The potential for savings accounts to protect young adult households from unsecured debt in periods 
of macroeconomic stability and decline. Social Service Review, 90(1), 83-129. https://doi.org/10.1086/685791.

Friedline, T., \& West, S. (2016). Financial education is not enough: Millennials may need financial capability to demonstrate healthier financial behaviors. Journal of Family and Economic Issues, 37(4), 649-671. https://doi.org/10.1007/s10834-015-9475-y.

Friedline, T., \& Kepple, N. (2017). Does community access to alternative financial services relate to individuals' use of these services? Beyond individual explanations. Journal of Consumer Policy, 40(1), 51-79. https://doi.org/10.1007/s10603-016-9331-y.

Friedline, T., Despard, M., Eastlund, R., \& Schuetz, N. (2017). Are banks' entry-level checking accounts safe and affordable? Comparing a stratified random sample of banks to safety and affordability guidelines. Ann Arbor, MI: University of Michigan, Center on Assets, Education, \& Inclusion (AEDI). https://www.newam erica.org/documents/1913/Are_Banks_Entry-Level_Checking_ Accounts_Safe_and_Affordable.pdf

Friedline, T., Despard, M., \& West, S. (2019). Does the composition of financial services in a community relate to an individual's savings account ownership? Journal of Community Practice, 27, 5-30. https://doi.org/10.1080/10705422.2019.1580652.

Friedman, M. (1957). A theory of the consumption function. Princeton, NJ: Princeton University Press.

Gjertson, L. (2016). Emergency saving and household hardship. Journal of Family and Economic Issues, 37, 1-17. https://doi. org/10.1007/s10834-014-9434-z.

Goodstein, R. M., \& Rhine, S. L. (2017). The effects of bank and nonbank provider locations on household use of financial transaction services. Journal of Banking \& Finance, 78, 91-107. https://doi. org/10.1016/j.jbankfin.2017.01.016.

Grinstein-Weiss, M., Yeo, Y., Despard, M., Zhan, M., \& Casalotti, A. (2010). Does banking experience matter? Differences of the bank and unbanked in Individual Development Accounts. Journal of Family and Economic Issues, 31(2), 212-227. https://doi. org/10.1007/s10834-010-9184-5.

Grinstein-Weiss, M., Guo, S., Reinertson, V., \& Russell, B. (2015). Financial education and savings outcomes for low-income IDA participants: Does age make a difference? Journal of Consumer Affairs, 49(1), 156-185. https://doi.org/10.1111/joca.12061.

Grinstein-Weiss, M., Despard, M., Guo, S., Russell, B., Key, C., \& Raghavan, R. (2016). Do tax-time savings deposits improve financial outcomes and reduce hardship among low-income filers? A propensity score analysis. Journal of the Society for Social Work and Research, 7, 707-728. https://doi.org/10.1086/689357.

Grinstein-Weiss, M., Russell, B. D., Gale, W. G., Key, C., \& Ariely, D. (2017). Behavioral interventions to increase tax-time saving: Evidence from a national randomized trial. Journal of Consumer Affairs, 51(1), 3-26. https://doi.org/10.1111/joca.12114.

Grinstein-Weiss, M., Cryder, C., Despard, M., Perantie, D., Oliphant, J., \& Ariely, D. (2018). The role of choice architecture in promoting saving at tax time: Evidence from a large-scale field experiment. Behavioral Science \& Policy, 3(2), 21-38. https://behavioral policy.org/articles/the-role-of-choice-architecture-in-promotingsaving-at-tax-time-evidence-from-a-large-scale-field-experiment/

Halpern-Meekin, S., Greene, S. S., Levin, E., \& Edin, K. (2018). The rainy day earned income tax credit: A reform to boost financial security by helping low-wage workers build emergency savings. RSF: The Russell Sage Foundation Journal of the Social Sciences, 4(2), 161-176. https://doi.org/10.7758/rsf.2018.4.2.08.

Harvey, C., John, D., \& Brown, K. (2018). Saving at work for a rainy day: Results from a national survey of employees (AARP Public Policy Institute Report). Retrieved from https://www.aarp.org/ content/dam/aarp/ppi/2018/09/rainy-day-national-survey.pdf

Haynes-Bordas, R., Kiss, D. E., \& Yilmazer, T. (2008). Effectiveness of financial education on financial management behavior and account usage: Evidence from a 'second chance' program.
Journal of Family and Economic Issues, 29(3), 362-390. https ://doi.org/10.1007/s10834-008-9115-x.

Hilgert, M. A., Hogarth, J. M., \& Beverly, S. G. (2003). Household financial management: The connection between knowledge and behavior. Federal Reserve Bulletin, 89, 309-322.

Huston, S. J. (2010). Measuring financial literacy. Journal of Consumer Affairs, 44(2), 296-316. https://doi.org/10.111 $1 / \mathrm{j} .1745-6606.2010 .01170 . x$.

Key, C., Tucker, J. N., Grinstein-Weiss, M., \& Comer, K. (2015). Tax-time savings among low-income households in the \$aveNYC program. Journal of Consumer Affairs, 49(3), 489-518. https://doi.org/10.1111/joca.12070.

Knoll, M. A., \& Houts, C. R. (2012). The financial knowledge scale: An application of item response theory to the assessment of financial literacy. Journal of Consumer Affairs, 46(3), 381-410. https://doi.org/10.1111/j.1745-6606.2012.01241.x.

Krumm, R., \& Kelly, A. (1989). Effects of homeownership on household savings. Journal of Urban Economics, 26(3), 281-294. https://doi.org/10.1016/0094-1190(89)90002-8.

Larrimore, J., Dodini, S., \& Thomas, L. (2016). Report on the economic well-being of U.S. Households in 2015. (Board of Governors of the Federal Reserve System Report). Retrieved from https://www.federalreserve.gov/2015-report-economic-wellbeing-us-households-201605.pdf

Leland, H. E. (1978). Saving and uncertainty: The precautionary demand for saving. In Uncertainty in economics (pp. 127-139). Academic Press.

Lusardi, A. (1998). On the importance of the precautionary saving motive. The American Economic Review, 88(2), 449-453. https ://www.jstor.org/stable/116965

Lusardi, A., \& Mitchell, O. S. (2007). Baby boomer retirement security: The roles of planning, financial literacy, and housing wealth. Journal of Monetary Economics, 54(1), 205-224. https ://doi.org/10.1016/j.jmoneco.2006.12.001.

Lusardi, A. (2008a). Household saving behavior: The role of financial literacy, information, and financial education programs (No. w13824). National Bureau of Economic Research. Retrieved from https://www.nber.org/papers/w13824

Lusardi, A. (2008b). Financial literacy: An essential tool for informed consumer choice? (NBER Working Paper No. 14084). Cambridge, MA: National Bureau of Economic Research. Retrieved from https://www.nber.org/papers/w14084

Lusardi, A., \& Mitchell, O. S. (2011). Financial literacy and planning: Implications for retirement well-being. (NBER Working Paper No. 17078). Cambridge, MA: National Bureau of Economic Research. Retrieved from https://www.nber.org/papers/ w17078

Lusardi, A., \& Mitchell, O. S. (2017). How ordinary consumers make complex economic decisions: Financial literacy and retirement readiness. Quarterly Journal of Finance, 7(03), 1750008. https ://doi.org/10.1142/S2010139217500082.

Lusardi, A., Michaud, P. C., \& Mitchell, O. S. (2017). Optimal financial knowledge and wealth inequality. Journal of Political Economy, 125(2), 431-477. https://doi.org/10.1086/690950.

Manturuk, K., Dorrance, J., \& Halladay, J. (2015). Building emergency savings through "impulse saving". A Fragile Balance (pp. 125-140). New York: Palgrave Macmillan US.

McKernan, S. M., Ratcliffe, C., \& Vinopal, K. (2009). Do assets help families cope with adverse events? (Perspectives on LowIncome Working Families Brief No. 10, Urban Institute). Retrieved from https://www.urban.org/research/publication/ do-assets-help-families-cope-adverse-events

Modigliani, F. (1966). The life cycle hypothesis of saving, the demand for wealth and the supply of capital. Social Research, 33, 160-217. https://www.jstor.org/stable/40969831 
Morduch, J., \& Schneider, R. (2017). The financial diaries: How Americans cope in a world of uncertainty. Princeton, NJ: Princeton University Press.

Mullainathan, S., \& Shafir, E. (2009). Savings policy and decision making in low-income households. In R. Blank \& M. Barr (Eds) 2009. Insufficient funds: Savings, assets, credit, and banking amongst low-income households. Russell Sage, New York pp121-146

Nam, Y., Kim, Y., Clancy, M., Zager, R., \& Sherraden, M. (2013). Do Child Development Accounts promote account holding, saving, and asset accumulation for children's future? Evidence from a statewide randomized experiment. Journal of Policy Analysis and Management, 32(1), 6-33. https://doi.org/10.1002/pam.21652.

National Federation of Community Development Credit Unions and Filene. (2015). Borrow and save ${ }^{\mathrm{TM}}$ feasibility study report. Retrieved from https://www.cdcu.coop/wp-content/uploa ds/2016/03/BorrowandSave_FeasibiltyStudy_FINAL.pdf

Pew Charitable Trusts. (2015). How do families cope with financial shocks: The role of emergency savings in family financial security (Issue Brief). Retrieved from https://www.pewtrusts.org/en/resea rch-and-analysis/issue-briefs/2015/10/the-role-of-emergencysavings-in-family-financial-security-how-do-families

Pew Charitable Trusts. (2016). Barriers to saving and policy opportunities: The role of emergency savings in family financial security (Brief). Retrieved from https://www.pewtrusts.org/ /media/asset s/2016/01/emergency-savings-report-3_artfinal.pdf?la=en

Pew Charitable Trusts. (2017). Are American families becoming more financially resilient? Changing household balance sheets and the effects of financial shocks (Issue Brief). Retrieved from https:// www.pewtrusts.org/ /media/assets/2017/04/financialshocks_brief .pdf

Red Tab Foundation. (2019). Supercharge your savings (Red Tab Savers Toolkit). Retrieved from https://www.redtabfoundation.org/ savers-toolkit/

Rhine, S. L., Di, W., Greene, W. H., \& Perlmeter, E. (2016). Savings account ownership during the great recession. Journal of Family and Economic Issues, 37(3), 333-348. https://doi.org/10.1007/ s10834-016-9489-0.

Rothwell, D. W., \& Han, C. K. (2010). Exploring the relationship between assets and family stress among low-income families. Family Relations, 59, 396-407. https://doi.org/10.111 1/j.1741-3729.2010.00611.x.

Rothwell, D. W., Khan, M. N., \& Cherney, K. (2016). Building financial knowledge is not enough: Financial self-efficacy as a mediator in the financial capability of low-income families. Journal of Community Practice, 24(4), 368-388. https://doi. org/10.1080/10705422.2016.1233162.

Schreiner, M., \& Sherraden, M. (2007). Can the poor save? Saving and asset building in individual development accounts. Transaction Publishers: Piscataway.

Servon, L. J., \& Kaestner, R. (2008). Consumer financial literacy and the impact of online banking on the financial behavior of lowerincome bank customers. Journal of Consumer Affairs, 42(2), 271-305. https://doi.org/10.1111/j.1745-6606.2008.00108.x.

Servon, L. (2017). The unbanking of America: How the new middle class survives. New York, NY: Houghton Mifflin Harcourt.

Sherraden, M., Schreiner, M., \& Beverly, S. (2003). Income, institutions, and saving performance in individual development accounts. Economic Development Quarterly, 17(1), 95-112. https ://doi.org/10.1177/0891242402239200.

Sherraden, M. S. (2013). Building blocks of financial capability. In J. Birkenmaier, M. S. Sherraden, \& J. Curley (Eds.), Financial capability and asset development: Research, education, policy, and practice (pp. 3-43). New York: Oxford University Press. https ://doi.org/10.1093/acprof:oso/9780199755950.003.0012.

Shobe, M. A., \& Boyd, S. A. (2005). Relationships between assets and perceived economic strain: Findings from an anti-poverty policy demonstration. Journal of Community Practice, 13(2), 21-44. https://doi.org/10.1300/J125v13n02_03.

Sikkel, D., \& van Meer, G. J. (2015). Stickiness: The value of saved money. Journal of Marketing Analytics, 3(3), 147-158. https:// doi.org/10.1057/jma.2015.13.

Thaler, R. H. (1999). Mental accounting matters. Journal of Behavioral Decision Making, 12, 183-296. https://doi.org/10.1002/ (SICI) 1099-0771(19990 9)12:3\%3c 183 :AID-BDM31 8\%3e3.0.CO;2-F.

Thompson, R., Wiedrich, K., Hernandez, M., Roll, S., Chun, Y., \& Lucas, T. (2020). Evaluating tax time savings interventions and behaviors. Washington, DC: Prosperity Now. Retrieved from https ://prosperitynow.org/resources/evaluating-tax-time-savings-inter ventions-and-behaviors

Tjur, T. (2009). Coefficients of determination in logistic regression models-A new proposal: The coefficient of discrimination. The American Statistician, 63(4), 366-372. https://doi.org/10.1198/ tast.2009.08210.

West, S., \& Friedline, T. (2016). Coming of age on a shoestring budget: Financial capability and financial behaviors of lower-income millennials. Social Work, 61(4), 305-312. https://doi.org/10.1093/ sw/sww057.

West, S., \& Mottola, G. (2016). A population on the brink: American renters, emergency savings, and financial fragility. Poverty \& Public Policy, 8(1), 56-71. https://doi.org/10.1002/pop4.130.

Woodyard, A. S., Robb, C., Babiarz, P., \& Jung, J. Y. (2017). Knowledge and practice: Implications for cash and credit management behaviors. Family and Consumer Sciences Research Journal, 45(3), 300-314. https://doi.org/10.1111/fcsr.12202.

Xiao, J. J., \& Noring, F. E. (1994). Perceived saving motives and hierarchical financial needs. Financial Counseling and Planning, 5(1), 25-44. https://www.afcpe.org/assets/journals/vol_52.pdf

Xiao, J. J., \& Olson, G. I. (1993). Mental accounting and saving behavior. Family and Consumer Sciences Research Journal, 22(1), 92-109. https://doi.org/10.1177/004677749302200105.

Publisher's Note Springer Nature remains neutral with regard to jurisdictional claims in published maps and institutional affiliations.

Mathieu R. Despard is an Associate Professor in the Department of Social Work at the University of North Carolina Greensboro and a Faculty Director with the Social Policy Institute at Washington University in St. Louis. His research focuses on financial inclusion and security among low- and moderate-income households and communities, and the capacity of nonprofit organizations serving these households and communities.

Terri Friedline is an Associate Professor and Faculty Director of Financial Inclusion at the Center on Assets, Education, and Inclusion at the University of Michigan School of Social Work and Research Fellow at New America. Her research focuses on financial system reform and consumer protections to ensure that people and communities have access to safe and affordable financial products and services.

Stacia Martin-West is an Assistant Professor at the University of Tennessee College of Social Work. Her research focuses on universal basic income, unconditional cash transfers, women's poverty and wealth inequality, and the affordable housing crisis. She recently completed the first evaluation of unconditional cash transfers in the context of environmental and economic disaster. 